\title{
Ervervet Horners syndrom
}

\begin{abstract}
Sammendrag
Bakgrunn. Skade i de sympatiske fibrenes forløp fra hypothalamus til øyet og ansiktet kan gi Horners syndrom, som består av den klassiske triaden miose, ptose og hemifacial anhidrose.
\end{abstract}

Materiale og metode. Denne oversiktsartikkelen er basert på egne erfaringer og skjønnsmessig utvalg av artikler funnet via ikke-systematisk søk i PubMed. Kasuistikker fra egen praksis tjener som eksempler.

Resultater. Basert på lokalisasjon av skaden klassifiseres ofte et Horners syndrom som enten sentralt, pre- eller postganglionært. Ved førstnevnte tilstand preges det kliniske bildet av symptomer og tegn fra sentralnervesystemet. Preganglionært syndrom skyldes som oftest tumor eller traume. Postganglionært syndrom er ofte assosiert med smerte/hodepine og ses hyppigst ved carotisdisseksjon eller under anfall med klasehodepine. Generelt er anhidrose sjeldent fremtredende, og ved postganglionær type i praksis fraværende. Farmakologiske tester kan benyttes i diagnostikken. Apraklonidin synes å være et godt alternativ til kokain for å få bekreftet et Horners syndrom. I utredningen anbefales generelt MR, eventuelt med spesialsekvenser.

Fortolkning. Forløpet av de langstrakte okulosympatiske fibrene er komplekst og ufullstendig forstått. Topografisk diagnostikk kan være utfordrende, men i majoriteten av tilfellene påvises en spesifikk årsak.

\section{Karl B. Alstadhaug}

karl.bjornar.alstadhaug@nlsh.no

Nevrologisk avdeling

Nordlandssykehuset Bodø

og

Institutt for klinisk medisin

Universitetet i Tromsø
Formålet med denne oversiktsartikkelen er å minne om et symptomkompleks som er relativt sjeldent, men som er relevant for flere medisinske og kirurgiske spesialiteter. Horners syndrom er en triade av symptomer (ensidig ptose, miose og hemifacial anhidrose) forårsaket av en skade eller dysfunksjon av den sympatiske innervasjonen til hodet og øyet. Årsakene til slik unilateral okulosympatisk parese (OSP) er tallrike, både godartede og ondartede, og de kan være lokalisert en rekke steder. Hos opptil 1/3 forblir årsaken ukjent (1). Bilateral okulosympatisk parese forekommer sjeldent, men det er rapportert ved systemiske autonome nevropatier (spesielt hos diabetikere) og ved cervikal spinal skade (2). Denne artikkelen vil redegjøre for relevant anatomi ved Horners syndrom og for diagnostisk evaluering av tilstanden.

\section{Materiale og metode}

Artikkelen bygger på et skjønnsmessig utvalg av litteratur som ble funnet via ikkesystematisk søk i PubMed, samt på egne erfaringer som nevrolog med spesiell interesse for temaet. Pasientene som presenteres har samtykket til at bilder og sykehistorier publiseres.

\section{Historikk}

Den sveitsiske legen Johan Friedrich Horner (1831-86) beskrev i 1869 en 40 år gammel kvinne som hadde hodepine og som var rød, tørr og varm i høyre ansiktshalvdel. Det virket som om høyre øye var litt innsunket og i tillegg hadde hun lett hengende øyelokk og anisokori med minst pupill på denne siden. Horner konkluderte med at symptomkomplekset måtte skyldes en lammelse i den sympatiske grensestrengen på halsen $(3,4)$. Dette udødeliggjorde hans navn, men det bør nevnes at den franske fysiologen Claude Bernard (1813-1878) allerede i 1852 hadde beskrevet et tilsvarende syndrom hos forsøkskaniner som fikk skåret over sympatiske fibre på halsen, og at Silas Weir Mitchell (1829-1914) i 1864 beskrev en isolert Horner-triade hos en 24 år gammel soldat med skuddskade i halsen (5).

Den norske øyelegen Johan Georg Ræder (1889-1956) var en av de første som beskrev et sentralt Horners syndrom. I 1918 rapporterte han i Norsk Magazin for Lagevidenskaben (6), og senere i Brain (7), om en ung mann som i måneder hadde hatt smerter i og rundt venstre øye. Pasienten hadde Horners syndrom, og i tillegg var det objek- tive tegn til affeksjon av trigeminusnerven. Det viste seg at pasienten hadde en tumor på skallebasis i fossa media, eller "paratrigeminalt» som foreslått av Georg Monrad-Krohn (1884-1964). Ræders syndrom er i dag erstattet med paratrigeminalt (okulosympatisk) syndrom. Idiopatiske former forekommer, men carotispatologi (disseksjon) overses nok i en del tilfeller (8). Smertefullt inkomplett Horners syndrom som forekommer daglig i perioder på uker skyldes sannsynligvis klasehodepine (pasient 1).

\section{Den okulosympatiske banen og pupillen}

Tradisjonelt beskrives den okulosympatiske banen (som strengt tatt ikke er en velavgrenset bane) som en seriekobling av tre sett nerveceller (fig 1). Den starter som et sentralt (1. ordens) nevron i hypothalamus. Dets akson ender høyt i ryggmargen. Herifra fortsetter et preganglionært (2. ordens) nevron med et akson som, via ventrale spinalrot og den sympatiske grensestrengen, ender i ganglion cervicale superius på halsen der det danner synapser med flere 3 . ordens nevroner. Aksonene til disse ender blant annet $\mathrm{i}$ pupillen. Oppbygningen og forløpet av den okulosympatiske banen er ikke fullstendig forstått og er langt mer komplisert enn denne skjematiske fremstillingen. Det følgende er en noe mer detaljert beskrivelse:

\section{Sentral del}

Isolert Horners syndrom ipsilateralt $\mathrm{i}$ forhold til skaden i hypothalamus har vært rapportert en rekke ganger. Hos én pasient var det også en liten ipsilateral lesjon i insula (9). Informasjon av emosjonell og sensorisk karakter, spesielt via insula og amygdala, ender i posterolaterale del av hypothalamus, og nyere data tyder på at den sentrale delen

\section{Hovedbudskap}

- Unilateral skade av okulosympatiske fibre gir Horners syndrom ipsilateralt

- Syndromet består av triaden miose, ptose og varierende grad av anhidrose

- Isolert Horners syndrom ses hyppigst ved postganglionær skade og er ofte forårsaket av carotisdisseksjon

- Grundig utredning hos spesialist med god kjennskap til relevant anatomi er nødvendig 
også inkluderer nevroner fra cerebral cortex $(10,11)$. Fra hypothalamus går det fibre til hjernestamme og ryggmarg. Blant annet er det projeksjoner til laterale parabrakiale kjerne $\mathrm{i}$ øvre og midtre del av hjernestammen samt til nucleus solitarius i dorsomediale del av medulla oblongata. Disse kjernene er igjen tett forbundet med ventrolaterale medulla (VLM). Signaler fra øvre del av ventrolaterale medulla formidles videre via aksoner lateralt $\mathrm{i}$ ryggmargens sidehorn (den intermediolaterale cellesøylen) til nivå $\mathrm{C} 8$ - Th3 der de preganglionære fibrene har sitt utspring (Budges ciliospinale senter). Det er verdt å merke seg at fibrene er ukrysset og at en skade derfor sitter ipsilateralt til de kliniske manifestasjonene.

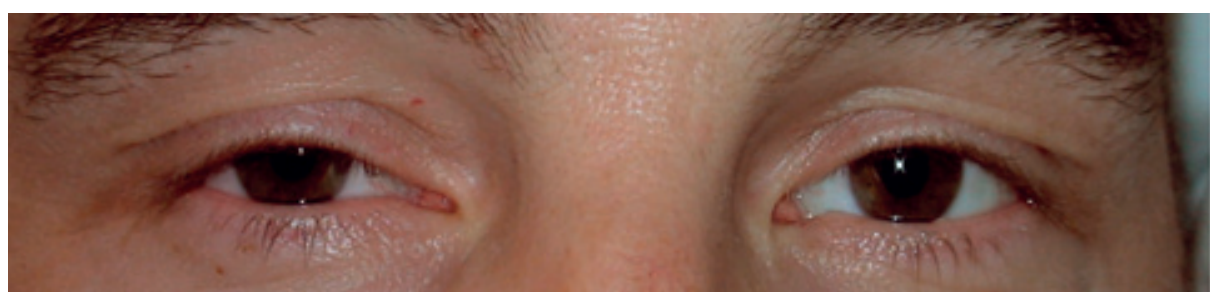

Pasient 1 Postganglionær lesjon (klasehodepine). Bildet viser et høyresidig Horners syndrom under et klasehodepineanfall. Den smale øyespalten gir inntrykk av at øyet er innsunket (pseudoenophthalmus). Mye taler for at klaseanfall har sitt opphav i hypothalamus, men de fleste studier indikerer at den okulosympatiske påvirkningen skjer perifert.

Ved sentral årsak påvirkes vanligvis svettingen $\mathrm{i}$ hele hodet, halsen, arm og overkropp på den affiserte siden. Anhidrosen overskygges imidlertid ofte av andre sym- ptomer og tegn. En sjelden gang ses Horners syndrom ved større skade i hjernen, som ved store mediainfarkter eller blødninger i thalamus. Av og til ses det ved mindre skader i

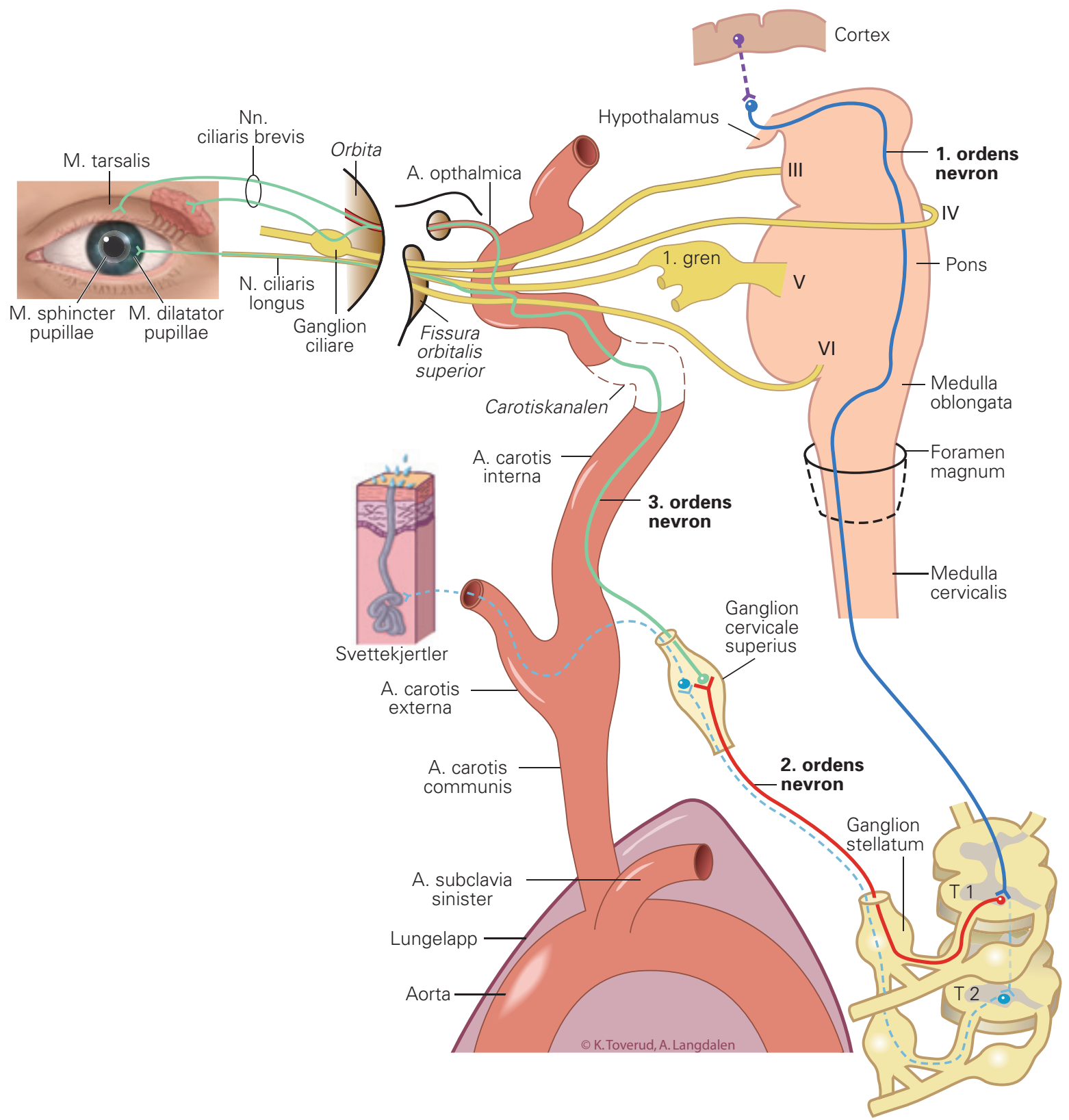

Figur 1 Den okulosympatiske banen - anatomi og klinisk presentasjon. Skade eller dysfunksjon i de langstrakte sympatiske fibrene til ansiktet og øyet kan forårsake syndromet 


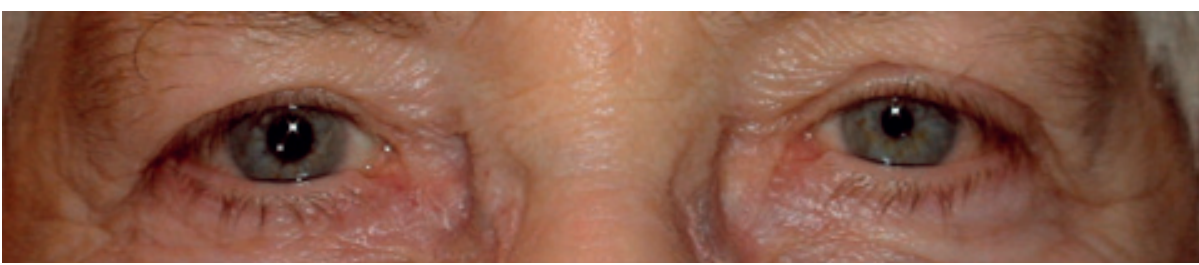

Pasient 2 Sentral skade (Wallenbergs syndrom). En hjerte- og karsyk kvinne i 70-årene fikk akutt profus svette, kvalme, dump smerte i høyre tinning, snøvlete tale og ble ustø. Senere på dagen merket hun svelgvans ker og svekket temperatursans i høyre hånd. Ved nevrologisk undersøkelse fant man venstresidig Horners syndrom, ipsilateral falltendens og ekstremitetsataksi, kontralateral nedsatt smerte- og temperatursans på truncus og i ekstremiteter samt lett svelgparese. Hun hadde et nesten komplett Wallenbergs syndrom. Cerebral MR bekreftet mistanken om et lite lateralt infarkt i venstre del av medulla oblongata.

øvre og midtre del av hjernestammen, men oftest er det assosiert med infarkt i laterale del av medulla oblongata (9). Det utgjør da en del av det klassiske symptomkomplekset Wallenbergs syndrom (pasient 2). Ikke bare ved vaskulære katastrofer, men også ved demyeliniserende sykdom og annen betennelsessykdom, romoppfyllende prosesser (svulster), syringomyeli/-bulbi og traumer mot nakkeregionen kan et sentralt Horners syndrom forekomme, da nesten alltid $\mathrm{i}$ en konstellasjon med andre nevrologiske symptomer og funn.

\section{Preganglionær del}

Fibrene til øyet forlater primært ryggmargen i nivå Th1, mens fibrene som regulerer svette (sudomotoriske) og årene i huden (vasomotoriske) i ansiktet går ut nedenfor i nivå Th2-Th3. Samtlige 2. ordens nevroner følger spinale ventralrøtter i de respektive nivåer og forlater columna spinalis som en del av spinalnerven, men forlater også denne nesten umiddelbart og går inn den sympatiske grensestrengen like lateralt for ryggvirvellegemet, i ganglion stellatum (uten å danne synapser), og fortsetter fra øvre åpning av brystkassen opp halsen til ganglion cervicale superius, som ligger i nivå med carotisbifurkaturen (C2-C3). Det er viktig å merke seg de preganglionære fibrenes forløp (fig 1a): tett inntil columna vertebralis, over apex av lungen og i nær relasjon til øvre ribbein, arteria carotis communis, arteria subclavia og vena subclavia samt thyroidea (10).

Patologi i samtlige av disse strukturene kan ved påvirkning av grensestrengen gi Horners syndrom med varierende grad av anhidrose. Direkte traume mot ryggmarg eller drag på plexus brachialis kan skade ventrale røtter og gi sympatiskusaffeksjon. Spontan pneumothorax er en velkjent (12), men uvanlig årsak (pasient 3). En rekke iatrogene årsaker er også beskrevet (kanylering av v. subclavia, halskirurgi, thoraxdren m.m.). Det kan sågar forekomme ved vanlig epiduralanestesi (anestetikumet vandrer kra-
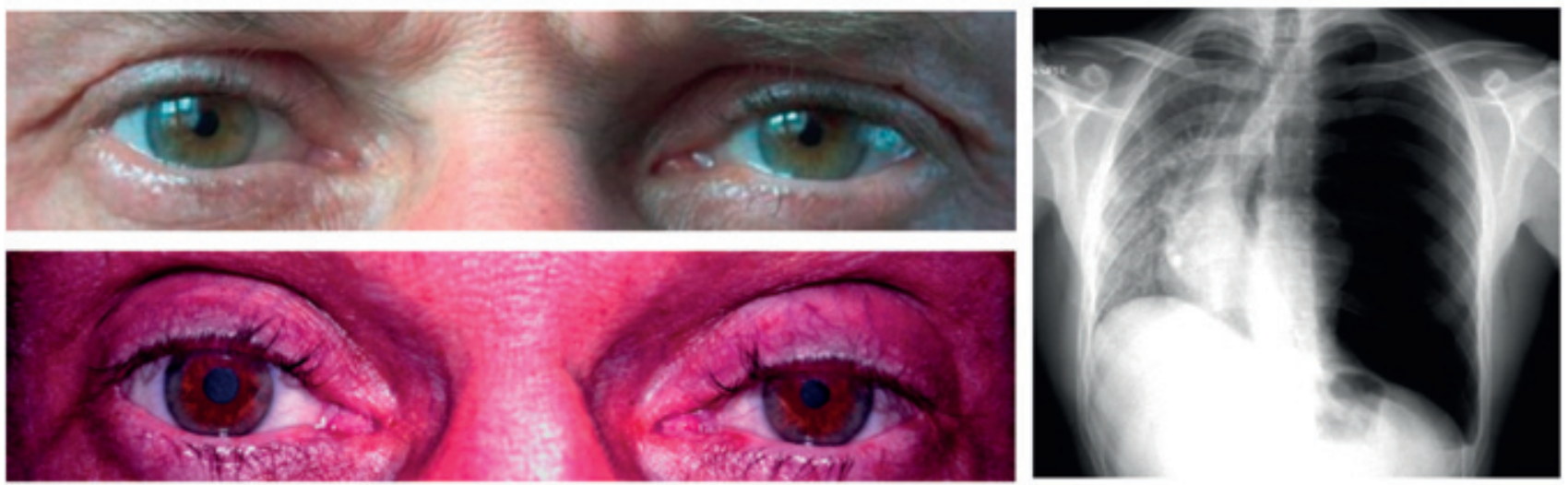

Pasient 3 Preganglionær lesjon (spontan trykkpneumothorax). En lang og tynn mann i 30-årene fikk akutt smerte i venstre thoraxhalvdel og ble tungpustet. Legg merke til hvor mye mer fremtredende anisokorien blir i dempet belysning (nederst). Røntgenbildet av lungene viste luft i pleurahulen og betydelig overskyting av trachea. Avklemming eller drag på den sympatiske grensestrengen pga. trykk og/eller apikal adheranse har vært postulert som mulige mekanismer for Horners syndrom i slike tilfeller (12).

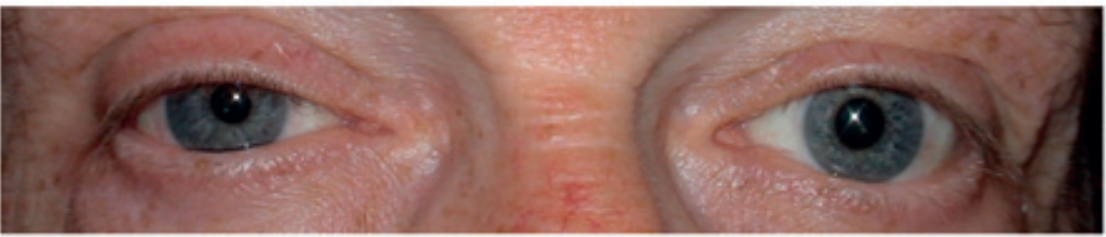

Pasient 4 Pancoasts tumor. En tidligere frisk 50 år gammel røyker hadde en måned tidligere merket at høyre øyelokk hang ned. I samme periode hadde han hatt noe smerter i høyre skulder. I de siste dager også med kortvarig utstråling i armen. Pupillografi bekreftet patologisk anisokori, og det var markant forlenget redilatasjonstid. CT thorax bekreftet infiltrerende tumor i høyre lungetopp (pil).

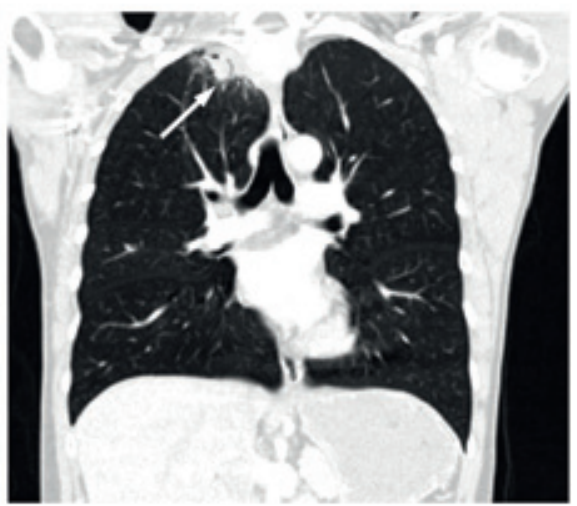


nialt) (13). Klassisk er det forårsaket av en tumor nær lungetoppen som gir nevrogen smerte i arm, atrofi i hånd, Horners syndrom og destruksjon av øvre ribbein, et syndrom beskrevet av Pancoast i 1932 (14). Det er imidlertid sjelden at isolert Horners syndrom er forste tegn på malign sykdom (15), men det forekommer (pasient 4).

\section{Postganglionær del}

Etter å ha forlatt ganglion cervicale superius tvinner 3. ordens nevroner seg rundt a. carotis interna $i$ et plexus i adventitia (plexus caroticus). Slik følger de arterien helt gjennom sinus cavernosus før fibre langs arteria ophthalmica fortsetter inn i øyehulen og ender $i$ Müllers muskel i øvre øyelokk (m. tarsalis superior/Mülleri) og mindre glatt muskulatur i nedre øyelokk (m. tarsalis inferior) samt til tårekjertelen. En annen del sender fibre i nervus nasociliaris (som kommer fra 1. gren av n. trigeminus) og innerverer $\mathrm{m}$. dilatator pupillae. I forløpet gjennom sinus cavernosus følger de postganglionære sympatiske fibrene nervus abducens, og disseksjoner eller oppfylninger i dette området gir vanligvis ikke isolert okulosympatisk parese, men det kan forekomme. Affeksjon av 3. ordens nevroner fører sjelden til anhidrose. Dette skyldes at majoriteten av vaso- og sudomotoriske fibre følger a. carotis externa. Isolert anhidrose, manifestert som kontralateral ensidig facial rødme (flushing) og svette, kalles Harlequins syndrom (16) og er ofte godartet $(16,17)$. De fleste pasienter med isolert Horners syndrom har en lesjon av 3. ordens nevron. Smerte på halsen og/eller hodepine skyldes da gjerne carotisdisseksjon (pasient 5).

\section{Pupillen}

Størrelsen på pupillen reguleres av den sympatisk innerverte $\mathrm{m}$. dilatator pupillae, som består av radiært forløpende glatt muskulatur og en ring av glatt muskulatur, $m$. sphincter pupillae, som er parasympatisk innervert (fig 1). Som kjent er pupillens størrelse først og fremst avhengig av belysningen. I mørke vil pupillene dilatere som følge av kombinert sympatisk dilatatorkonstriksjon og sfinkterrelaksasjon. Ved mørkelegging av pupillene er en rask reflektorisk pupillutvidelse avhengig av sympatikus. En okulosympatisk skade vil derfor medføre at den affiserte pupillen vil bli mer avhengig av en passiv og langsom sfinkterrelaksasjon. Asymmetrien vil føre til en anisokori som er mest uttalt etter 4-5 sekunder. Først etter 10-20 sekunder slutter pupillen å dilatere. Fenomenet kalles redilatasjonsforsinkelse (redilatation lag) og er et kjennetegn på Horners syndrom.

\section{Utredning og diagnostikk}

Det kan være vanskelig å skille en reell okulosympatisk skade fra såkalt pseudoHorners syndrom. En liten forskjell i størrelsen på de to pupillene $(>0,4 \mathrm{~mm})$ i et normalt individ er ikke uvanlig (hos opptil $20 \%$ ) (18). Normale, men «tunge øyelokk» kan også gi inntrykk av ptose. Patologisk nedhengende øyelokk skyldes svekket $\mathrm{m}$. tarsalis eller m. levator palpebra, og kan ha flere årsaker, men ensidig lett ptose assosiert med ipsilateral miose skyldes sjelden annet enn okulosympatisk parese.

\section{Kliniske funn}

Miose. De mest karakteristiske funnene er en relativ miose av pupillen og en anisokori som fremtrer tydeligst i dempet belysning (pasient 3). Ved direkte og indirekte belysning vil man vanligvis finne normal pupillreaksjon, men redilatasjonsforsinkelse kan eventuelt observeres. Infrarødt lys (ved for eksempel pupillometri) vil avdekke at pupillen forblir relativt liten i komplett mørke.

Ptose. Et lett nedhengende øyelokk, typisk et par millimeter, er karakteristisk. Man kan også observere lett elevasjon av nedre øyelokk, «opp-ned-ptose». Ptosen kan gi inntrykk av enoftalmus (pasient 1).

Anhidrose. Avbrutt sympatisk innervasjon til ansiktets blodårer og svettekjertler vil kunne gi rødme (flushing) pga. vasodilatasjon, og tørrhet pga. manglende svetteutsondring. Denervasjonen vil imidlertid kunne gjøre blodårene supersensitive for sirkulerende adrenalin, og derfor er vanligvis ansiktshalvdelen med den sympatiske defekten blekest. Anhidrose er relativt sjeldent fremtredende, men når det observeres (skillet går eksakt i midtlinjen av ansiktet) eller påvises (termografi eller påføring av alizarinpudder), utelukker det vanligvis postganglionær skade. Unntaket er forstyrret facial rødme og svette $\mathrm{i}$ et lite område medialt $\mathrm{i}$ pannen. Det går nemlig noen få sudomotoriske fibre langs a. carotis interna. Disse når (via n. supraorbitalis) huden i dette området.

\section{Pupillometri}

I klinisk praksis er «det blotte øyet» ofte tilstrekkelig til å vurdere om det foreligger

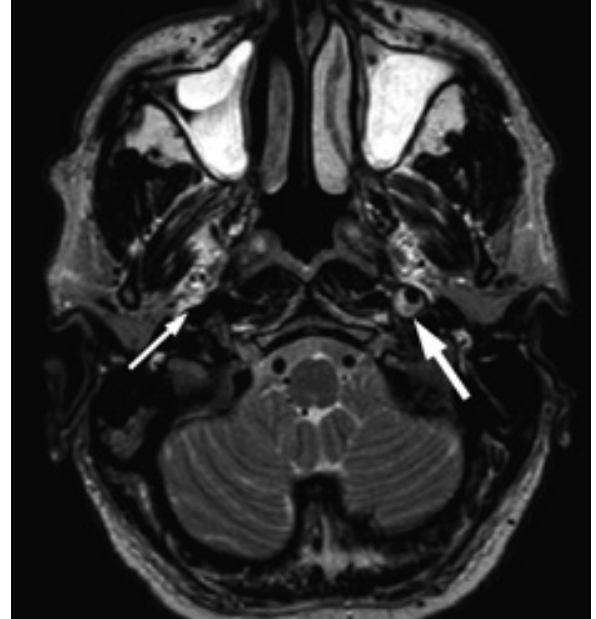

Pasient 5 Postganglionær lesjon (carotisdissek sjon). En tidligere frisk mann i 50-årene våknet med venstresidig hodepine. Utredning avdekket et Horners syndrom forårsaket av en carotisdisseksjon. Aksialt T1-vektet bilde gjennom skallebasis viser en venstresidig carotisdisseksjon (tykk pil). Den halvmåneformede signalendringen i arterien består av blod i karveggen (bildet er tatt uten kontrast) og innsnevrer lumen. På høyre side er det normalt «flow void»signal (tynn pil).

ptose og miose. Redilatasjonsforsinkelse kan også raskt og enkelt observeres uten spesielle hjelpemidler, men sensitiviteten er lav (15). Ved å bruke digitalt infrarødt pupillometer kan de dynamiske egenskapene til pupillene vurderes mer objektivt og vitenskapelig (19). Et raskt, standardisert lysstimulus vil utløse pupillrefleks, og ut fra hurtige digitale fotografier av pupillresponsen kan en rekke verdier kalkuleres. Sen dilatasjon (økt redilatasjonstid) ses typisk ved sympatisk defekt.

\section{Farmakologisk testing}

I de fleste lærebøker og artikler som omhandler topografisk diagnostikk ved Horners syn-

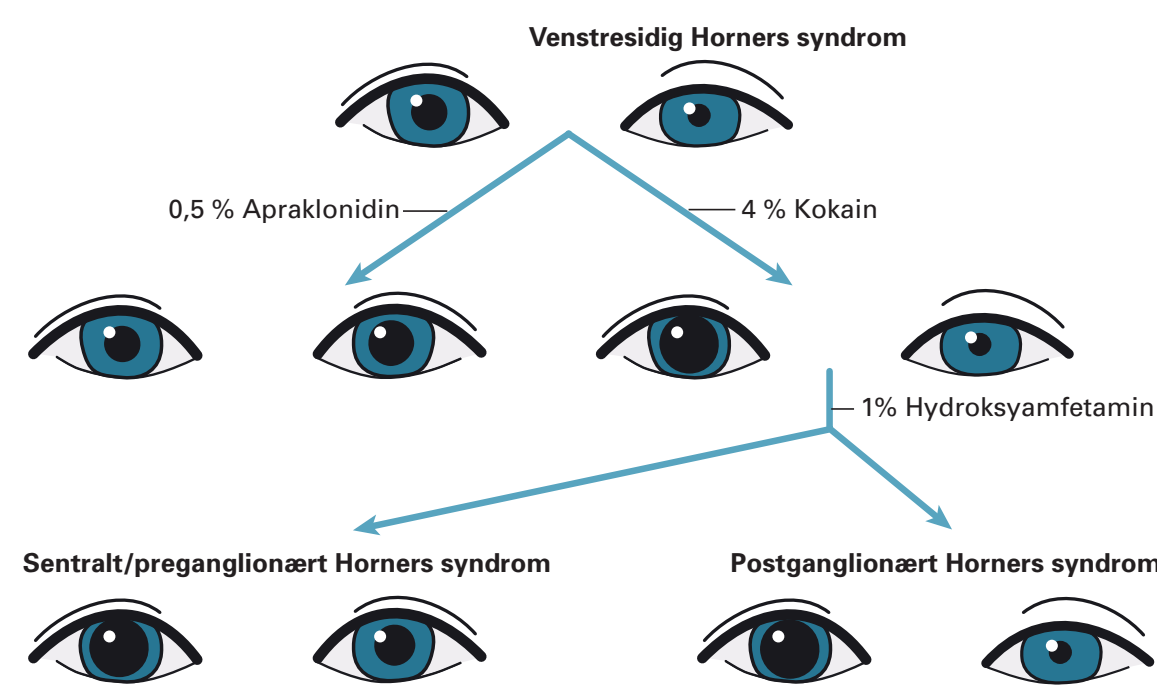

Figur 2 Farmakologisk testing ved bruk av øyedråper kan benyttes i topografisk diagnostikk av Horners syndrom 

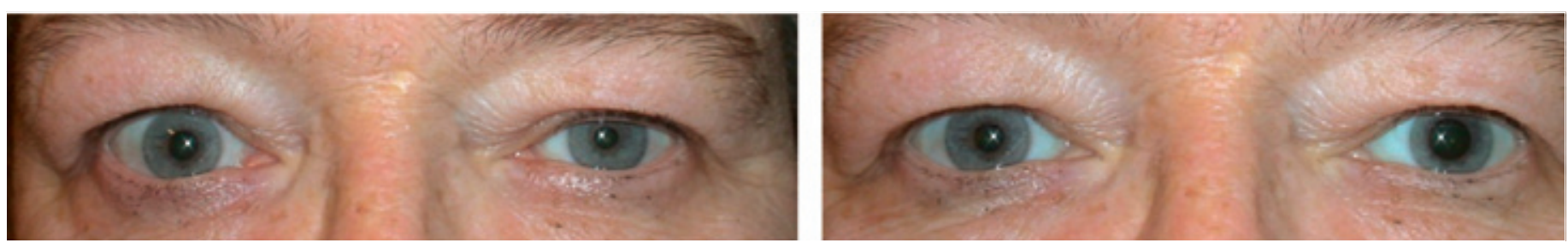

Pasient 6 Apraklonidintest. Venstresidig Horners syndrom. Bildet til venstre viser pasienten før det ble dryppet 1 dråpe lopidine ${ }^{\circ}$ (5mg/ml) i hvert øye. Bildet til høyre er tatt 45 minutter senere. Anisokorien er reversert og ptosen er opphevet.

drom, for eksempel en artikkel i dette tidsskriftet for knappe 20 år siden (20), er det inngående omtale av bruk av øyedråper med kokain og amfetamin (fig 2). Selv om de har inngått som gullstandarder i studier av Horners syndrom, er de i praksis vanskelig å få tak i. Apraklonidin (Iopidine) er et anvendelig og godt alternativ til kokain (2). Utgangspunktet for farmakologisk testing er at dersom 3. ordens okulosympatiske nevron skades, vil noradrenalin (NA) forsvinne fra den nevromuskulære synapsekløften og $\alpha_{1}$-reseptor i den glatte dilatatormuskulaturen vil ikke bli stimulert. Det vil imidlertid kunne skje en oppregulering av $\alpha_{1}$-reseptorer slik at det oppstår hypersensitivitet for stimulering med noradrenerge legemidler (18). Ved 1.- eller 2.ordens okulosympatisk parese vil 3 . ordens nevroner fortsatt frigjøre noradrenalin, men i reduserte mengder.

Kokainøyedråper, som regel i $4 \%$ løsning, kan skaffes via de fleste sykehusapotek. Stoffet virker indirekte sympatomimetisk ved å binde seg til et transporterprotein $\mathrm{i}$ den sympatiske nerveenden og redusere reopptak av noradrenalin fra synapsespalten slik at det blir økt stimulering av $\alpha_{1}$-reseptorer og dermed pupilldilatasjon. Maksimal effekt ses etter ca. tre kvarter. På grunn av opphevet eller redusert noradrenalinfrigjøring ved okulosympatisk parese vil pupillen ved Horners syndrom forbli uendret. Sensitiviteten er imidlertid lav, og testen kan ikke differensiere mellom 1., 2. og 3. ordens lesjon.

Hydroksyamfetaminøyedråper (1\%) får intakte 3 . ordens sympatiske nevroner til å tømme lagret noradrenalin fra endeterminalen. Dersom kokaintest allerede har bekreftet Horners syndrom, vil altså en dilaterende pupill etter amfetamintest indikere sentraleller preganglionær skade, mens manglende respons taler for postganglionær skade. Testen må utføres 1-2 døgn etter kokaintest og har da relativt god diagnostisk nøyaktighet. Det er vanskelig å få tak i hydroksyamfetamin, og testen er derfor lite praktisk.

Apraklonidinøyedråper $(0,5 \%)$ synes å være et relativt pålitelig alternativ til kokain for å bekrefte at det foreligger et Horners syndrom (2). Ut fra klinisk erfaring fungerer det utmerket. Effekten baserer seg på en hypersensitiv dilatator $\mathrm{i}$ iris pga. denervasjon (se ovenfor). I akuttfasen, før $\alpha_{1}$-reseptorer er oppregulert, vil derfor falskt negative resultater forekomme. Apraklonidin er en direkte alfaagonist med svak $\alpha_{1}$-aktivitet, men sterk $\alpha_{2}$-aktivitet. I et normalt øye vil $\alpha_{2}$-stimulering tendere til å redusere nivået av noradrenalin, og effekten av $\alpha_{1}$-stimuleringen er ikke tilstrekkelig til å dilatere pupillen. En hypersensitiv pupill ved Horners syndrom vil imidlertid dilatere. Faktisk vil man kunne reversere anisokorien slik at pupillen med Horners syndrom blir størst. En eventuelt reversering av ptosen kan også forekomme (pasient 6).

\section{Radiologi}

Det finnes ingen klare retningslinjer for hvordan et Horners syndrom bør utredes. Ved en sentral skade vil som oftest assosierte symptomer og tegn bidra til å lokalisere årsaken, og MR av cerebrum eller cervikotorakalmedulla vil avdekke den. Også ved preganglionær skade, som oftest forårsaket av traume eller tumor, vil ledsagende symptomer og tegn være veiledende. I fravær av traume bør et nyoppstått Horners syndrom assosiert med ipsilateral skulder-/armsmerte gi mistanke om okkult malignitet. Ved mistanke om lesjon i lunge, mediastinum eller ventralt på hals vil $\mathrm{CT}$ med kontrast ofte være tilstrekkelig for å lokalisere lesjonen. MR kan imidlertid bli nødvendig dersom det er mistanke om affeksjon av cervikalcolumna eller plexus brachialis.

De fleste isolerte Horners syndrom er postganglionære og kan volde diagnostisk hodebry. Carotisdisseksjon er en av de viktigste årsakene som bør utelukkes. Utredning med MR-angiografi er å foretrekke fremfor CT (og ultralyd), da disse undersøkelsene er for lite sensitive, spesielt ved disseksjoner i nærheten av skallebasis (21). Også konvensjonell angiografi kan være utilstrekkelig dersom lumen av karet ikke innsnevres (22). Horners syndrom ledsaget av parese i 3., 4 ., 5. eller 6. hjernenerve gir mistanke om lesjon i sinus cavernosus, $i$ det paratrigeminale området eller i orbitale apex. Ved mistanke bør man utføre grundige, fokuserte MRundersøkelser av disse områdene.

Alle pasientene har gitt samtykke til at artikkelen blir publisert.

\section{Karl B. Alstadhaug (f. 1972)}

er spesialist i nevrologi. Han er overlege i nevrologi og førsteamanuensis. Ingen oppgitte interessekonflikter.
Litteratur

. Patel S, Ilsen PF. Acquired Horner's syndrome clinical review. Optometry 2003: 74: 245-56.

2. Koc F, Kavuncu S, Kansu T et al. The sensitivity and specificity of $0.5 \%$ apraclonidine in the diagnosis of oculosympathetic paresis. Br J Ophthalmol 2005: 89: 1442-4

3. Horner JF. Über eine Form von Ptosis. Klin Monbl Augenheilkd 1869; 7: 193-8.

4. Fulton JF. Horner and the syndrome of paralysis of the cervical sympathetic. Arch Surg 1929; 18: 2025-39.

5. Pearce JMS. Fragments of neurological history London: Imperial College Press, 2003.

6. Raeder JG. Et tilfælde av intrakraniel sympaticus lammelse. Norsk Mag Lægevidensk 1918; 79 . 999-1017.

7. Raeder JG. Paratrigeminal paralysis of oculopupillary sympathetic. Brain 1924; 47: 149-58

8. Solomon S, Lustig JP. Benign Raeder's syndrome is probably a manifestation of carotid artery disease. Cephalalgia 2001; 21: 1-11.

9. Nagy AN, Hayman LA, Diaz-Marchan PJ et al. Hor ner's syndrome due to first-order neuron lesions of the oculosympathetic pathway. AJR Am J Roentgenol 1997: 169: 581-4.

10. Amonoo-Kuofi HS. Horner's syndrome revisited: with an update of the central pathway. Clin Anat 1999; 12: 345-61.

11. Marx JJ, lannetti GD, Mika-Gruettner A et al. Topodiagnostic investigations on the sympathoexcitatory brain stem pathway using a new method of three dimensional brain stem mapping. J Neurol Neurosurg Psychiatry 2004: 75: 250-5

12. Thakar C. Hunt I, Anikin V. Horner's syndrome in a patient presenting with a spontaneous pneumothorax. Emerg Med J 2008; 25: 119-20.

13. Evans JM, Gauci CA, Watkins G. Horner's syndrome as a complication of lumbar epidural block. Anaesthesia 1975; 30: 774-7.

14. Pancoast HK. Superior pulmonary sulcus tumor. Tumor characterized by pain, Horner's syndrome destruction of bone and atrophy of hand muscles. J Am Med Assoc 1932: 99: 1391-6.

15. Wilhelm H. The pupil. Curr Opin Neurol 2008; 21: $36-42$

16. Lance JW, Drummond PD, Gandevia SC et al. Harlequin syndrome: the sudden onset of unilateral flushing and sweating. J Neurol Neurosurg Psychiatry 1988; $51: 635-42$

17. Wasner G, Maag R, Ludwig J et al. Harlequin syndrome - one face of many etiologies. Nat Clin Pract Neurol 2005; 1: 54-9.

18. Meyer BC. Incidence of anisocoria and difference in size of palpebral fissures in five hundred norma subjects. Arch Neurol Psychiatry 1947; 57: 464-8.

19. Kjesbu S, Moksnes K, Klepstad P et al. Bruk av pupillometri og pupillreaksjonar i medisinsk forsking. Tidsskr Nor Lægeforen 2005; 125: 29-32.

20. Salvesen R. Horners syndrom - Med spesiell omtale av topografisk diagnostikk. Tidsskr Nor Lægeforen 1991; 111: 48-52.

21. Lee JH, Lee HK, Lee DH et al. Neuroimaging strategies for three types of Horner syndrome with emphasis on anatomic location. AJR Am J Roentgenol 2007; 188: W74-81.

22. Brown J Jr. Danielson R, Donahue SP et al. Horner's syndrome in subadventitial carotid artery dissection and the role of magnetic resonance angiography. Am J Ophthalmol 1995; 119: 811-3.

Mottatt 2.9. 2010, første revisjon innsendt 9.12. 2010, godkjent 20.1. 2011. Medisinsk redaktør Are Brean. 